\title{
MEASURING THE EFFECTIVENESS OF PUBLIC RELATIONS IN PRIVATE SECTOR ORGANIZATIONS: A RESEARCH ON LOCAL AND INTERNATIONAL INSURANCE COMPANIES
}

\author{
Engin ÇELEBİ \\ Çukurova University, Türkiye \\ engincelebi@cu.edu.tr \\ https://orcid.org/0000-0001-5791-8080
}

\begin{tabular}{l|l|} 
Atıf & $\begin{array}{l}\text { Çelebi, E. (2022). Measuring The Effectiveness of Public Relations in Private Sector } \\
\text { Organizations: A Research on Local and International Insurance Companies. The Turkish } \\
\text { Online Journal of Design Art and Communication, 12 (2), 280-290 }\end{array}$ \\
\hline
\end{tabular}

\begin{abstract}
In private sector organizations, customer loyalty is a marketing-oriented outcome. The best way to gain customer loyalty, especially in the service industry, is to establish a long-term relationship with customers. This requires placing greater value on customers' feelings and needs. In addition, to adding value to organizations such as creating customer loyalty, strengthening corporate identity, image and reputation, it also contributes to services to increase customer awareness. In this study, a research was conducted on insurance companies serving as private sector organizations in Turkey. Within the scope of the research, a questionnaire was applied to a total of 214 people, 104 people receiving service from international insurance companies and 110 people receiving service from local insurance companies. According to the research data, a positive and significant correlation was found between "Desire to maintain a long-term relationship", "Desire to recommend to others" and, "Satisfaction", "Trust" and "Communicative competence" felt from the insurance company employees. Research data revealed that public relations perceptions have strategically positive effects on organizations' perceptions of social identity, reputation, emotional commitment of customers and acquiring new customers.
\end{abstract}

Keywords: Public Relations, Customer Loyalty, Communication Management, Insurance Companies, CRM.

\section{ÖZEL SEKTÖR KURULUŞLARINDA HALKLA İLISSKILERIIN ETKINLLIĞINII ÖLÇME: YEREL VE ULUSLARARASI SIGORTA ŞİRKETLERİ ÜZERINE BİR ARAŞTIRMA}

\section{$\ddot{O ̈ Z}$}

Özel sektör kuruluşlarında müşteri bağlılı̆̆ pazarlama odaklı bir sonuçtur. Özellikle de hizmet sektöründe müşteri bağl1lığını elde etmenin en iyi yolu müşterilerle uzun vadeli bir ilişki kurmaktır. $\mathrm{Bu}$ ise müşterilerin duygu ve ihtiyaçlarına daha fazla değer vermeyi gerektirir. Müşteri bağlllığının oluşturulması, kurumsal kimliğin, imajın ve itibarın güçlendirilmesi gibi kuruluşlara değer katmasının yanı sıra müşteri duyarlılıklarını artırmaya yönelik hizmetlere de katkı sağlamaktadır. Bu çalışmada, Özel sektör kuruluşları olarak Türkiye'de hizmet veren sigorta şirketleri üzerinde bir araştırma yapılmıştır. Araştırma kapsamında, Uluslararası sigorta şirketlerinden hizmet alan 104 kişi ve yerel sigorta şirketlerinden hizmet alan 110 kişi olmak üzere toplam 214 kişiye anket uygulaması yapılmıştır. Araştırma verilerine göre, "Uzun vadeli bir ilişki sürdürme isteğì" ve "Başkalarına tavsiye etme isteği" ile Sigorta şirketi çalışanlarından duyulan "memnuniyet", "güven" ve "İletişim yeterlilik" arasında 
pozitif yönde ve anlamlı bir korelasyon bulunmuştur. Araştırma verileri, halkla ilişkiler algılamalarının kuruluşların sosyal kimlik algıları, itibarları, müşterilerin duygusal bağlılıkları ve yeni müşteriler kazanılması üzerinde stratejik açıdan olumlu etkilerinin olduğunu ortaya çıkartmıştır.

Anahtar Kelimeler: Halkla İlişkiler, Müşteri Bă̆lllı̆̆l, İletişim Yönetimi, Sigorta Şirketleri, CRM.

\section{INTRODUCTION}

Integrating public relations (PR) practices into success strategies such as customer loyalty, relational quality and reputation management will contribute to the field in theoretically and practically. Public relations practices play an important role in the relations of organizations with their customers. Public relations practices are a leading dimension in gaining the trust, satisfaction and loyalty of customers. Because public relations perceptions contribute to the formation of positive attitudes and behaviors. Competition in private sector organizations is increasing at local, national and international levels. Public relations practices of private sector organizations have an important place in revealing and growing the value of the sector. Demonstrating the importance of public relations in private sector organizations may show parallelism with revealing the importance of their relations with organizational results. For this reason, it is desired that public relations practices contribute to the marketing and sales targets of the organizations. Private sector organizations are trying to maintain their existence in globalized market conditions. Therefore, customer representatives should be able to keep up with the changes brought about by globalization. For this, there is a need for applications that will associate communicative practices with sociocultural variables.

Measuring the quality of communicative skills and their effectiveness on target audiences is difficult and complex. Satisfaction, long-term relationship and willingness to recommend are the most used elements in customer relationship research. Impact factors, interconnections and cause-effect relationships have been studied in different sectors. It can be said that all these dimensions are interrelated and can affect each other. On the other hand, these dimensions can be contradictory among themselves. Because these factors, which are evaluated in the corporate context, are also related to factors such as corporate image, corporate reputation and corporate identity.

The communicative process is a very complex element that can be determined according to physiological and psychological effects that measure attitudes towards cognitive, emotional and behavioral processes. All of this happens through the experiential learning process and can change over time. It can be said that cognitive and emotional factors are the precursor of behavioral commitment. Therefore, it is important to investigate how these are reflected in attitudes. Because attitudes include all variables. Insurance service buyers with positive attitudinal results can become advocates and supporters of insurance companies. It can be said that a communication that will be created in the form of positive comments in word of mouth communication and social media channels can increase trust and create value for the corporate identities of insurance companies.

The importance of maintaining and developing relationships with customers has always been included in marketing communications. Customer relations departments should advise organizations on how their corporate position can be achieved for relational purposes. Therefore, customer representatives are required to predict, report and interpret customer trends. In this study, it is aimed to determine effective strategies for public relations practices in order to increase customer loyalty, trust and satisfaction, which is one of the most important achievements of private sector organizations. In addition, It is aimed to explain the attitudinal and behavioral effects of public relations practices on customers. In this context, the relationships between public relations perceptions and customers' behavior, perceptions and attitudes will be analyzed.

\section{Public Relations in Private Sector Organizations for Customer Trust, Loyalty and Satisfaction}

Customers' cognitive (economic interests, competence) and emotional (a positive opinion, trust) intentions can influence their behavioral choices. For this reason, public relations strategies that can be sustained in private sector organizations should be put forward and their effectiveness should be evaluated according to their results. 
Heath and Coombs (2006:7) defined public relations as "the management function that entails planning, research, publicity, promotion, and collaborative decision making to help any organization's ability to listen to, appreciate, and respond appropriately to those persons and groups whose mutually beneficial relationships the organization needs to foster as it strives to achieve its mission and vision". This definition encompasses both the management role and key functions of public relations in private sector organizations.

Public relations practitioners can have very different roles in private sector organizations. Demands and expectations of target audience members may also differ in private sector organizations operating in different fields and conditions. Despite all these roles and complexity, the power, impact and evaluation of public relations practices in private sector organizations can only be made on the basis of financial results. For this reason, it is necessary to understand how public relations is organized in organizations, how it is perceived, its function, responsibilities, duties and effects. For this reason, marketing, advertising and media relations constitute the working areas of many public relations departments in private sector organizations.

The purpose of public relations in private sector organizations is to encourage all stakeholders to participate in corporate goals. The interactions to be established for this purpose should be the responsibility of all departments of the organizations and should not be seen as the duty of only the public relations departments. Research is needed to identify the wishes, concerns, attitudes, perceptions of the target audiences and their impact on relational outcomes.

Public relations practitioners must make interactive connections among different audiences and articulate their organization's goals and achievements. It should continue its activities by focusing on relational results that contribute not only to the benefit of the organization but also to the benefit of society. For this purpose, it is necessary to understand the relationships between environmental factors and public relations and to help senior managers to understand public relations practices in an integrated way.

Public relations departments in private sector organizations are also expected to show value and profit returns as part of the marketing function. Due to increased competition, expectations and social demands, the distinctive features of public relations are much broader and more effective. From a marketing perspective, public relations tends to be viewed as a promotional function, primarily seen as providing tactical support to marketing campaigns. However, the PR department may not be effective in the decision-making process in the organizations (Çelebi, 2020:772).

Trust is defined as a "a willingness to rely on an exchange partner in whom one has confidence" (Moorman, Zaltman, and Deshpande 1992:315). On the other hand, According to Bowden's research (2011:211) "trust was not found to be a strong determinant of recommendation or return". According to the results of a research on customer relations, trust is the most important variable in relational outcomes and, relational outcomes are important factors for supportive behaviors. (Çelebi and Bilir, 2019:465). Ki and Nekmat (2015:697) revealed in their research on bank customers that perceived relational quality has a positive effect on corporate impression (image creation) and individual attitudes, and this triples the supportive behavior of customers.

"Loyalty is the willingness of someone - a customer, an employee, a friend - to make an investment or personal sacrifice in order to strengthen a relationship" (Reichheld, 2003:3). Allen and Meyer (1990:849) state that customer loyalty includes three components: affective commitment, continuance commitment, and normative commitment. Customer loyalty is defined as the positive attitude of customers towards a particular product or service provider that results in repeat purchase behavior (Anderson and Srinivasan, 2003:125). Customer loyalty should be measured using both attitudinal and behavioral components in order to distinguish between true loyalty and false loyalty (Kumar and Shah, 2004:310). Loyalty is the level of commitment to purchase goods or services continuously in the future (Oliver, 1999:35). Customers who are emotionally attached to the brand tend to own it and discuss the brand with other customers (Pansari and Kumar, 2017:304). 
Commitment and trust are the two most important variables in the literature and play a central role in relationship marketing (Morgan and Hunt, 1994:25).

"Satisfaction is the consumer's fulfillment response. It is a judgment that a product or service feature, or the product or service itself, provided (or is providing) a pleasurable level of consumption-related fulfillment, including levels of under-or over-fulfillment" (Oliver, 1997:13). Oliver (1997:2) stated that customer satisfaction is defined as an evaluation process or a result of this process. Oliver (1997:2) also explained that customer satisfaction is the satisfaction response of the consumer. Satisfaction occurs when customers' expectations are met positively or when there is a satisfactory situation related to consumption (Bowden, 2011:214).

Kotler and Armstrong (2017:4) define marketing as a function that creates value for customers by establishing positive relationships. Managing relationships with customer groups often takes place simultaneously through public relations and marketing. The aim is to maintain long-term relationships with existing customers and attract new customers to the organization. The aim is to maintaining longterm relationships with existing customers and attract new customers to the organization (Kotler and Keller, 2006).

Public relations departments act as intermediaries between organizations and their target audiences by developing positive relationships to achieve mutually desired results. Public relations adds economic value to private sector organizations. Because mutually beneficial relationships between organizations and their target audiences enable organizations to achieve their goals more easily. Mutually beneficial relationships can be defined as both cause and effect.

The value of customer relationships comes from the relationships organizations develop and maintain with their strategic audiences. Considering customers' opinions is as valuable as interacting. Because it can be predicted that this will produce better and longer-lasting relationships.

In traditional public relations approaches, target audiences can be used as a tool to meet corporate policies or marketing needs. The value given to target audiences can be better understood through the dialogue process. For dialogue, effective methods should be determined, feedback opportunities must be provided, and full, timely and accurate information must be provided to target audiences.

According to Katie, Brian and Hyunmin (2016:29) public relations practitioner power in integrated communication structures is related to structural and influence-based (reward, legitimate, expert and coercive) power. Caywood (2012: 6) argued that public relations offers the greatest communication power to an organization due to its experience and ability to use of variety of communication-based strategies and tactics to building stakeholder relationships.

According to Smith and Place's (2013:168) research, public relations practitioners gain strength at integrated marketing communication (IMC) thanks to expertise in digital and social media. According to Kotler (2002:4), "marketing is a social and managerial process by which individuals and groups obtain what they need and want through creating and exchanging products and value with others".

It is claimed that public relations has already lost its marketing power (Hutton, 2010:205). In the digital age, different public relations strategies may be needed in order for customers with different cultural and sociodemographic characteristics and different views and opinions can act towards a common goal. Because understanding the subjective perceptions and expectations of customers is as important as understanding the results of public relations practices. Public relations can be thought of as focused on maintaining and improving the relationship of organizations with their customers in order to ensure repeat purchases. The PR unit is critical in predicting the behavioral characteristics of relational outcomes for current and potential customers' purchase intentions. The effect of marketing PR efforts is that satisfying and retaining existing customers is often cheaper than to acquire new ones.

Research Article - This article was checked by iThenticate 


\section{Creating Research Hypotheses}

It is necessary to determine which public relations dimension is prioritized by the target audience groups in the private sector organization and whether there is a cause effect relationship between these dimensions. Because the degree and quality of the relationships of organizations with their target audiences is a fundamental result. The quality of relationships with target audiences produces many positive results. Relational quality elements and the harmony of expectations, experiences and values are psychological and multidimensional concepts. For this reason, the results of public relations should be examined on the basis of the types of relations that organizations establish with their target audiences. Relationship management can be made effective with contemporary public relations processes and techniques. The conceptualization of public relations as relationship management transforms the core values of public relations into a field where high-quality relations with target audiences are sought and obtained.

Public Relations is driven by establishing and maintaining long-term relationships that are influenced by trust, commitment and satisfaction (Hon and Grunig, 1999). Customer relations management (CRM) can be activated with modern public relations processes and techniques. Interaction is an important factor in relational outcomes. However, communicating with target audiences should not mean establishing relationships with them. In order to manage relations with the target audience, the effect level of relational dimensions should be focused.

CRM is an important area of research in the public relations literature. The aim is to manage uncertainties, remove concerns, build and maintain strong long-term relationships with target audiences. To understand the effectiveness of corporate public relations, it is important to look at the communicative process and relational outcomes. Relationship building strategies focus on those that benefit both the organization and its audience. Many different approaches have been adopted to measure the effectiveness of corporate public relations.

While creating the research questionnaire, Chi and Chan's (2019:289-290) research on the insurance agent-customer duo and Çelebi's (2020) research on the effectiveness of corporate communication were used. In research scale, for customer satisfaction "e.g. I am happy to receive service from this company"; For the desire to maintain a long-term relationship "e.g. I will maintain a long-term service relationship with this company"; For the request to recommend the insurance company "e.g. I often like the recommendations this employee offers"; For to measure communicative competence, "e.g. The employees of this Insurance company are highly engaged (beyond material interests) towards their customers."; For to measure the strength of the company "e.g. The service and service quality of this insurance company is good"; For the service gift received from the insurance company "e.g. Sometimes, I'm buying extra discounts etc. from this insurance company" substances were used.

The data for customer representatives are considered as an attitudinal dimension and independent variables. For this reason, 3 hypotheses were formed as follows.

Hypothesis 1: There is a positive and significant correlation between "Customer satisfaction", "Professional competence" and "Communicative competence" of insurance company employees.

Hypothesis 2: There is a positive and significant correlation between "Professional competence" and "Communicative competence" of insurance company employees and "Willingness to maintain a longterm relationship" with the insurance companies of the customers.

Hypothesis 3: There is a positive and significant correlation between "Professional competence" and "Communicative competence" of the insurance company employees and "Willingness to recommend the insurance companies to others" of customers.

Customers' satisfaction with the Insurance company, their desire to maintain a long-term relationship and their willingness to recommend to others may depend on factors other than the company's employee. Therefore, the next hypotheses are designed to measure the power and influence of the insurance company. 
Hypothesis 4: There is a positive and significant correlation between the power of the insurance company (industry size, reputation, etc.) and customers' satisfaction, desire to maintain a long-term relationship and, willingness to recommend to others.

Hypothesis 5: There is a positive and significant correlation between the service gifts (discounts, extra benefits, etc.) received from the insurance company and customers satisfaction, their desire to maintain a long-term relationship, and their willingness to recommend to others.

\section{A Research On The Effectiveness Of Public Relations In Private Sector Organizations}

In this research, the effectiveness of public relations will be used to measure the quality of relations between private sector organizations and their customers. Thus, it is aimed to contribute to the literature. Customers receiving services from insurance companies in Turkey as private sector organizations are included in the research. There are many types of insurance. Fields such as earthquake insurance and traffic insurance, which are compulsory in Turkey, are not included in the scope of the research. Only optional fields such as health insurance and life insurance were included in the research. A questionnaire was applied to 214 people, 104 people receiving service from International insurance companies and 110 people receiving service from local insurance companies, and it was aimed to compare the results. Of the sample, $42 \%(\mathrm{n}=90)$ were female and $58 \%(\mathrm{n}=124)$ were male. The age range of the participants is as follows; 37 people were 18-30 years old, 41 people were 31-40 years old, 57 people were 41-50 years old, and 79 people were 51 and more. The data were collected from the participants in the digital environment on a voluntary basis with the survey technique. Data collection took approximately 1 month.

The time required for the formation of an attitude towards the insurance company served is determined as 1 year. The survey was applied to customers who regularly received service from insurance companies for at least 1 year. Questionnaire items were measured on a 5-point likert scale (1-strongly disagree, 5- strongly agree). In the reliability analysis for the internal consistency of the questionnaire, the Cronbach Alpha value of the 20 -item scale was measured as ,863. This value shows that the items used in the scale are at an acceptable level and consistent with each other.

\section{Research Results}

In order to find an answer to Hypothesis 1, the average satisfaction of the participants from the Insurance company (employee) from which they receive service was measured. While the service satisfaction rate from international companies was 4.53 out of 5 , the service satisfaction rate from local companies was measured as 4.22. The correlation between "Customer Satisfaction", "Professional competence" and "Communicative competence" of the insurance company employees is shown in Table 1.

Table 1: Correlation between Customer Satisfaction, Professional Competence and Communicative Competence

\begin{tabular}{lllcr} 
& & N & Correlation & Sig. \\
\hline Customer & \& Professional competence & 214 &, 895 &, 000 \\
Satisfaction & \& Communicative competence & 214 &, 880 &, 000 \\
& & & & \\
\hline
\end{tabular}

According to the results in Table 1, a positive and significant relationship was found between customer satisfaction, professional competence and communicative competence of insurance company employees. This result supports hypothesis 1. According to the results of the Anova test, the difference between the averages of local and international insurance companies with $95 \%$ confidence was not statistically significant. $(\mathrm{F}=975,445>0.05)$

To test Hypothesis 2, the correlation between the "Professional competence", "Communicative competence" of the Insurance company employees and the "Willingness to maintain a long-term relationship with the insurance companies" of the customers was examined and a positive significant relationship was found. This result supports hypothesis 2 . The results are shown in table 2 . 
The Turkish Online Journal of Design, Art and Communication - TOJDAC

ISSN: 2146-5193, April 2022 Volume 12 Issue 2, p.280-290

Table 2: Correlation between Willingness to Maintain a Long-Term Relationship, Professional Competence and Communicative Competence

\begin{tabular}{llccc} 
& & N & Correlation & Sig. \\
\hline Maintain a Long- & \& Professional competence & 214 &, 850 &, 000 \\
Term Relationship & \& Communicative competence & 214 &, 830 &, 000 \\
& & & & \\
\hline
\end{tabular}

While the willingness to maintain long-term relations with international companies was found 4.42 out of 5, this rate was measured as 4.16 in local companies. According to the results of the Anova test, the difference between the averages of local and international insurance companies with $95 \%$ confidence was not statistically significant. ( $\mathrm{F}=890,375>0.05)$

To test Hypothesis 3, the correlation between Insurance company employees' "Professional competence", "Communicative competence" and, "Willingness of customers to recommend Insurance companies to others" was examined. A significant positive correlation was found between them and this result supports hypothesis 3 . The results are shown in table 3.

Table 3: Correlation between Willingness to Recommend to Others, Professional Competence and Communicative Competence

\begin{tabular}{llccc}
\hline & & N & Correlation & Sig. \\
\hline Recommend & \& Professional competence & 214 &, 855 &, 000 \\
To Others & \& Communicative competence & 214 &, 840 &, 000 \\
& & & & \\
\hline
\end{tabular}

While the willingness of the customers to recommend the International insurance companies they receive service to others was 4.48 out of 5 , this rate was 4.31 for customers of the local companies. According to the results of the Anova test, the difference between the averages of local and international insurance companies with $95 \%$ confidence was not statistically significant. $(\mathrm{F}=895.562>0.05)$

To explain Hypothesis 4, the correlation between the reputation of the insurance company (industry size, recognition, etc.) and customer satisfaction, desire to maintain a long-term relationship, and willingness to recommend to others is shown in table 4 .

Table 4: Correlation Between Reputation of the Insurance Company and Customers' Satisfaction, Desire to Maintain a LongTerm Relationship, Recommendation to Others

\begin{tabular}{lllll}
\hline & & N & Correlation & Sig. \\
\hline Company's & \& Customers' Satisfaction & 214 &, 645 &, 000 \\
Reputation & \& Desire to Maintain a Long-Term Relationship & 214 &, 595 &, 000 \\
& \& Recommendation to Others & 214 &, 620 &, 000 \\
\hline
\end{tabular}

As seen in Table 4, a positive but moderate relationship was found between the reputation of the insurance company and customer satisfaction, desire to maintain a long-term relationship, and willingness to recommend to others. This result partially supports hypothesis 4 .

Research Article - This article was checked by iThenticate 
Table 5: Correlation between Gifts from Insurance Companies and Customer Satisfaction, Desire to Maintain a Long-Term Relationship, Recommendation to Others

\begin{tabular}{lllll}
\hline & & N & Correlation & Sig. \\
\hline \multirow{2}{*}{ Gifts From } & \& Customers' Satisfaction & 214 &, 865 &, 000 \\
Companies & \& Desire to Maintain a Long-Term Relationship & 214 &, 805 &, 000 \\
& \& Recommendation to Others & 214 &, 880 &, 000 \\
\hline
\end{tabular}

According to the results in Table 5, a positive and high level of correlation was found between gifts received from insurance companies and customer satisfaction, desire to maintain a long-term relationship, and willingness to recommend to others. This result supports hypothesis 5 .

\section{CONCLUSION}

It can be said that customer relations are primarily related to the communicative process. Therefore, according to the research data, "customer satisfaction" provided the strongest positive effect in both organizations. Insurance companies need to focus on improving their relations with all their target audiences through effective communicative methods. In order for the quality of the relationships of insurance companies with their customers to be long-term and sustainable, it is necessary to understand how relational results occur, to measure how these relational results may change over time, and to devote time to development. While doing these, it is necessary to act in accordance with ethical and moral values, to show honesty and goodwill, and to understand all the needs and expectations of insurance service buyers. Responding these as much as possible, having good corporate representatives, etc. strategies are important in showing customers that they are valuable.

The feelings and thoughts of customers can change over time. Also, relational outcomes can be affected by many social factors. It can be said that for the result of all communicative practices, an element of trust must first be established. Insurance companies need to communicate effectively with service users in order to create and increase the sense of trust. However, building trust, especially in the insurance sector, is not just under the control of customer representatives. For this reason, measurements should be made about what constitutes the element of trust in insurance service buyers and how to increase trust, and its positive and negative effects should be noted. Otherwise, trust will depend mainly on results, not on the development of relationships.

There may be many different factors underlying the relationship between insurance service buyers' attitudes towards insurance companies and their communicative perceptions. Creating mutual values for these factors, defining psychological processes, making use of effective interpersonal communication techniques, establishing sincerity, etc. strategies can contribute to improvement of communicative quality. Interpersonal communication ability is an important resource as a customer relationship management tool. In this way, positive human relationships are established, developed and maintained.

The communicative process is not only about exchanging information, but also about building positive attitudinal perceptions. Anxiety and worries of insurance service buyers can affect their cognitive, emotional and behavioral attitudes. Eliminating or minimizing negative emotions is one of the main issues that customer representatives should focus on in the insurance industry.

Improving the quality of the relations between insurance companies and service buyers is an important indicator of the professional success potential of customer representatives. For this, customer representatives must have extremely effective communication skills. Active listening and effective feedback are important in the communicative process. In order to increase the quality of the communicative process and to develop effective communication strategies, it is necessary to give inclusive and consistent messages.

The study of Tabrani, Amin and Nizam (2017:823) shows that trust has a significant relationship with commitment and customer intimay, but there is no significant relationship found between trust and 
customer loyalty. According to results commitment and intimacy have a significant relationship with customer loyalty.

It is essential for insurance companies to communicate with their target audiences in a transparent and effective manner in order to increase and maintain the sense of loyalty. For this, in order to establish and maintain positive relationships with target audiences, it is necessary to have information about their differences. Engaging with target audiences should not mean building positive relationships with them.

Iglesias et al. (2020:151) conducted a survey of 1101 customers of health insurance services brands. The results show that Corporate Social Responsibility (CRS) affects customer loyalty both directly and indirectly through co-creation and customer trust.

In competitive environments, private sector organizations can use communicative applications (CRS) to gain the attention, approval and support of their customers by making them an important component of their corporate structuring. For this reason, public relations management should be seen as the management principle of organizations. However, According to the literature review (McKie and Willis, 2012: 851) it is a common view that public relations units continue their activities under marketing imperialism.

According to sectoral differences, many different approaches can be used to improve customer relations. According to Bakir et al. (2018:311) PR professionals focus largely on what they perceive as nonmanipulative forms of organized persuasive communication, while promotional culture scholars focus on 'salesmanship' in public life.

It is necessary to understand and meet the needs and demands of customers, to ensure a common perspective and harmony of values, to strengthen relations based on effective communication and dialogue, to develop relations with all stakeholders by paying attention to moral and ethical responsibilities are necessary to ensure long-term sustainability.

Lesmena, Sutarman and Sunardi (2021:43) research results show that service quality has a positive and significant direct effect on customer satisfaction, customer satisfaction has a significant direct effect on customer loyalty, but service quality does not have a positive and significant direct effect on customer loyalty. Customer satisfaction has full mediated between service quality and customer loyalty. Similarly, El-Adly (2019:331) found in his research that customer satisfaction has a direct and significant positive effect on customer loyalty.

Customer relationship development strategies represent proactive approaches that organizations can use to develop or maintain quality relationships with their customers. Different interaction strategies may be required to be accountable, socially responsible, resolve disputes and conflicts, contribute to corporate reputation, and understand the responsibilities of organizations and their customers. In order to maintain and support the customer relations approach in insurance companies with a more dynamic and interactive approach, various benefits need to be revealed. Strategies such as engaging in dialogue with interpersonal (face-to-face) communication, requesting for regular feedback, showing that opinions and suggestions will be evaluated and implementing them contribute to the continuation of relational results and improve quality. In addition, interpersonal communication (face-to-face communication) has important effects on thoughts and behaviors. Therefore, we can say that interpersonal communication should be included in all public relations practices (Celebi, 2021:768).

To define and classify the differences of the target audience, to ensure equality and the protection common values, to be aware of their interests and expectations, to ensure their participation in corporate purposes with the principles of dialogue and effective communication, to gain trust, to establish a longterm relationship, to value creation process and thus establishing of sustainable relations will contribute positively to corporate performance.

Future research should examine the links between environmental factors (geographical conditions) for insurance purchases and their consequences on audience relations. Organizations can often implement

Research Article - This article was checked by iThenticate 
a one-size-fits-all strategy. On the other hand, technical research needs to be continued to customize communicative applications. Future research should explore the causes of psychological factors that may affect the relational outcomes of insurance service buyers with insurance companies and how they change over time. Reasons and demographic factors, such as past experiences and cultural differences of insurance service buyers, may be included in future research. More research is needed to determine the quality of public relations strategies and to develop strategies to establish these principles in insurance companies.

\section{REFERENCES}

Allen, N. J. \& Meyer, J. P. (1990). "The measurement and antecedents of affective, continuance and normative commitment to the organization". Journal of Occupational and Organizational Psychology, 63(1), 1-18.

Anderson, R.E. \& Srinivasan, S.S. (2003). "E-Satisfaction and E-Loyalty: A Contingency Framework". Psychology \& Marketing, 20(2), 123-138.

Bakir, V., Herring, E., Miller, D. \& Robinson, P. (2018). "Organized Persuasive Communication: A new conceptual framework for research on public relations, propaganda and promotional culture", Critical Sociology, 45(3), 311-328.

Bowden, J.L-H. (2011). "Engaging the Student as a Customer: A Relationship Marketing Approach". Marketing Education Review, 21(3), 211-228.

Caywood, C. (2012). The Handbook of Strategic Public Relations and Integrated Marketing Communications (2nd ed). New York: McGraw Hill.

Chi, N-W. \& Chen, P-C. (2019). "Relationship matters: How relational factors moderate the effects of emotional labor on long-term customer outcomes". Journal of Business Research 95, 277-291.

Çelebi, E. \& Bilir, F.P. (2019). "Effects Of Relationship Management On Sports Consumers: A Research On Private Sports Centers". In: Recent Advances in Social Sciences, Eds. By. Efe, R., Koleva, I., Öztürk, M., and Arabac1, R., Cambridge Scholars Publishing, Newcastle, 452-468.

Çelebi, E. (2020). "Public relations in public institutions: A research on the effectiveness of communication process". Journal of Human Sciences, 17 (3), 768-779.

Çelebi, E. (2021). "The effect of organization-public relations on sports fan loyalty". Journal of Human Sciences, 18(1), 94- 103.

El-Adly, M.I. (2019). "Modelling the relationship between hotel perceived value, customer, satisfaction, and customer loyalty". Journal of Retailing and Consumer Services 50, 322-332.

Heath, R. L. \& Coombs, W.T. (2006). Today’s public relations. California: SAGE.

Hon, L.C. \& Grunig, J.E. (1999). "Guidelines for measuring relationships in public relations". Institute for Public Relations, 1-40.

Hutton, J. G. (2010). "Defining the relationship between public relations and marketing: Public relations' most important challenge". In R. L. Heath (Ed), The Sage Handbook of Public Relations (pp. 509-522). Thousand Oaks, CA: Sage.

Iglesias, O, Markovic, S. Bagherzaeh, M, Sigh, J.J. (2020). “Co-creation: A Key Link Between Corporate Social Responsibility, Customer Trust, and Customer Loyalty". Journal of Business Ethics $163,151-166$.

Ki, E.J. \& Nekmat, E. (2015). "Decomposing Impression from Attitude in Relationship Management Outcomes". Journal of Promotion Management, 21 (6), 685-702.

Kumar, V. \& Shah, D. (2004). "Building and sustaining profitable customer loyalty in the 21st century". Journal of Retailing, 80 (4), 317-330. 
Kotler, P. (2002). Marketing Management. Millennium Edition. Upper Saddle River, New Jersey: Prentice-Hall, Inc.

Kotler, P. \& Keller, L. (2006). Marketing Management. (12 ${ }^{\text {th }}$ ed). New Jersey: Prentice- Hill.

Kotler, P. \& Armstrong, G. (2017). Principles Of Marketing (9th ed.). New York, Pearson Education.

Lesmana, R., Sutarman, A. \& Sunardi, N. (2021). "Building A Customer Loyalty Through Service Quality Mediated by Customer Satisfaction". American Journal of Humanities and Social Sciences Research (AJHSSR), 5(3), 38-45.

McKie, D. \& Willis, P. (2012). "Renegotiating the terms of engagement: Public relations, marketing, and contemporary challenges", Public Relations Review 38, 846-852 .

Morgan, R.M. \& Hunt, S.D. (1994). "The Commitment-Trust Theory Of Relationship Marketing”. Journal of Marketing, 58 (3), 20-38.

Moorman, C., Zaltman, G. \& Deshpande, R. (1992). "Relationships between providers and users of market research: The dynamics of trust within and between organizations". Journal Of Marketing Research, 29, 314-328.

Oliver, R.L. (1997). Satisfaction: A Behavior Perspecfive on the Consumer. NY: McGraw-Hill.

Oliver, R.L. (1999). “Whence Consumer Loyalty?”. Journal of Marketing 63, 33-44.

Pansari, A. \& Kumar, V. (2017). "Customer Engagement: The Construct, Antecedents, and Consequences", J. of the Acad. Mark. Sci. 45, 294-311.

Place, K.R., Smith, B.G. \& Lee, H. (2016). "Integrated Influence? Exploring Public Relations Power in Integrated Marketing Communication”. Public Relations Journal, 10(1), 1-36.

Reichheld F. F. (2003). “The One Number You Need To Grow”. Harvard Business Review, 81(12), 4654.

Smith, B. G., \& Place, K. R. (2013). "Integrating Power? Evaluating Public Relations Influence in an Integrated Communication Structure". Journal of Public Relations Research, 25(2), 168-187.

Tabrani, M., Amin, M. \& Nizam, A. (2018). "Trust, commitment, customer intimacy and customer loyalty in Islamic banking relationships". International Journal of Bank Marketing, (36)5, 823-848. 